DOI: https://doi.org/10.32839/2304-5809/2020-5-81-90

UDC 81'37:811.133.1

Bozhko Iryna

Sumy A.S. Makarenko State Pedagogical University

\title{
LISTS OF NAMES IN RAYMOND QUENEAU'S «LES GEVRES COMPLETES DE SALLY MARA»: STYLISTIC FUNCTIONS
}

Summary. The article deals with stylistic functions of lists of names in «Les œuvres complètes de Sally Mara» by Raymond Queneau. We analysed several lists formed by different types of names and arrived at the conclusion that Raymond Queneau's lists serve the purpose of creating metafiction, underlying fictitiousness and artificiality of the story. They are examples of fine humour of the real author, Raymond Queneau, and fictional author of the collection, Sally Mara. They are parodic; they contain puns, irony, and absurd. Proper names within a list, as compared to appellatives, dispose of higher potential to produce nets of allusions because they carry a huge load of connotative meaning linking a proper name to a certain epoch, sphere of human activity, etc. without naming them explicitly. And last but not least, lists of proper names are a powerful means of text melody.

Keywords: enumeration, list, proper name, semantics, stylistics, Raymond Queneau.

Божко I.C.

Сумський державний педагогічний університет імені А.С. Макаренка

\section{СТИЛІСТИЧНІ ФУНКЦІЇ ПЕРЕЛІКІВ ІМЕН У «LES CEUVRES COMPLETES DE SALLY MARA» PEMOHA KEHO}

Анотація. У статті висвітлено проблему стилістичних фрункцій переліків імен у «Les œuvres complètes de Sally Mara" Ремона Кено. Нами проаналізовано декілька переліків, утворених різними типами власних назв: антропонімами, етнонімами, ергонімами у вигляді абревіатур. Одним із нетрадиційних переліків $\epsilon$ мішаний список, у якому поєднуються прізвища французьких письменників та науковців з їх типовими висловлюваннями. Частково переліки в текстах Ремона Кено допомагають локалізувати часові та просторові межі дії, однак через їхню гетерогенність вони мають набагато вищий експресивний потенціал. Ми дійшли висновку, що переліки власних назв у творчості Ремона Кено слугують творенню метамистецтва, підкреслюючи фіктивність та штучність оповіді, що почасти зближує сюрреалістичну творчість письменника з напрямком постмодернізму чи навіть метамодернізму. Окрім того, переліки - це ще і зразки тонкого гумору реального автора, Ремона Кено, та фіктивної авторки, Саллі Мари. Вони пародійні, слугують засобами творення каламбурів, іронії та абсурду, а отже, є елементами мовної гри. Власні назви у переліках, якщо їх порівнювати із загальними назвами, мають суттево вищий потенціал створювати мережі алюзій, адже вони є носіями значно вагомішого конотативного значення, яке поєднує власну назву 3 певною епохою, галуззю людської діяльності, сакральними текстами тощо, не називаючи їх експліцитно. Врешті, на звуковому рівні переліки власних назв є потужним інструментом творення мелодики тексту за рахунок того, що вони містять численні алітерації та асонанси, парономазії тощо. Компоненти переліків у багатьох випадках фонетично подібні або ж мають спільний компонент (повторюване ім'я або прізвище, частину абревіатури, фонетичні варіанти власної назви тощо). Попри поширену думку, у переліках власних назв кожна з них не втрачає ваги, а навпаки - підсилюе своє значення, набуває нового рівня експресивності. Розуміння абсурдних переліків власних назв, як кожної назви окремо, так і сукупності назв як цілісної єдності, слугуе більш глибокій інтерпретації художнього тексту, виявленню нових шарів значення. Подальші дослідження у цьому напрямку можуть передбачати поглиблене дослідження переліків у творчості Ремона Кено - як у прозі, так і в поезії.

Ключові слова: перелік, власна назва, семантика, стилістика, Ремон Кено.

$\mathrm{T}$ he problem setting. A human being has always had a tendency to organize their environment. This urge is reflected by numerous lists of no matter what surrounding us in everyday life. What about fiction? Today's postmodern literature is known for its abundance of lists, although this phenomenon is not new for literature in general. Among these enumerations lists of proper names are not a rare case. Despite that fact, they are still poorly examined from the point of view of stylistics. Are they different from other lists? What advantages do they have if compared to the lists of appellatives? We are going to try to answer all these questions while examining "Les œuvres complètes de Sally Mara» by Raymond Queneau. Therefore, the object of this research is the lists present in this collection consisting of a diary, a novel and a series of aphorisms the author attributed to a fictional Sally Mara. The subject of our investigation is the stylistic effect produced by such lists.
The analysis of the investigations and published works. Our research is based on numerous sources, which, actually, prove that lists are not a phenomenon typical to postmodern texts only. According to Jan Alber postmodernist lists serve a metafictional or self-reflexive function. Other than that, they highlight our compulsive need to impose order on chaos, and, of course, in postmodern narratives these catalogues celebrate variety and plurality [1, p. 342]. An important research was published under the title «Liste et effet liste en littérature» [17], which gives a rather exhaustive commentary of what a list is and how it works in a literary text starting from Rabelais and Pascal and finishing by the present-day fiction. The lists are also regarded as language games, e. g. the lists by Rabelais are considered to be burlesque and parodic [10, p. 43, 62], the lists of fatrasies, which ascend to the Middle Ages [10, p. 29], give the idea of the impossible, carnivalesque world. 
Perhaps, the most important for our study is the article by Cécile de Bary (2011), in which the author analyzes the lists of the oulipiens - mainly French writers and mathematicians seeking new ways of literary expression. Raymond Queneau was one of the founders of this group. Unfortunately, we do not find any deep analysis of Queneau's proper names lists in prose, although the author mentions one of the poems by Queneau, consisting uniquely of names of statues: "Sainte Geneviève et Henri Murger // Clémence Isaure et Gustave Flaubert // Anne de Beaujeu Blanche de Castille // Ratisbonne et la Joie de la Famille // SainteBeuve et Marie de Médicis» [3, p. 419; 20, pp. 66-67]. As one may note, the use of lists and enumerations is quite typical to the Raymond Queneau's works.

Aim setting. The purpose of this article is to analyse the stylistic functions of lists in the collection "Les œuvres complètes de Sally Mara» by Raymond Queneau. The lists are examined on the different levels of language; their role in language play present throughout Queneau's works is discussed.

The presentation of the main material. As it is noted by Barbara Folkart, "the enumeration of proper names, which is considered as a proof of insignificance, shows, on the contrary, to what extend a proper name can serve to support the connotative meaning, especially when it is engaged in the web of paradigmatic and syntagmatic relations at the same time" [9, p. 233]. Let us consider if this is true according to the examples from the text.

To begin with, lists of names serve as a means of phonetic expressivity. In the following example from "Le journal intime de Sally Mara» we observe a number of stylistic means, beginning with assonance (Mac Adam) and alliteration (Connan O'Connan) and ending with parallelism (compare the similar structure of enumerated names: George Connan O'Connan, Phil Mac Connan, Timoléon Mac Connan) and paronomasia (Mack O'Grégor Mac Connan):

«J'étais en retard et rougissante ; effectivement de nombreuses personnes se trouvaient là : le maître et madame me accueillirent aimablement et protectivement et me présentèrent les intellectuels et tuelles présents. Le poète Connan O'Connan, son ami le poète Grégor Mac Connan et son beau-frère le poète Mack O'Grégor Mac Connan ainsi que le barde druide O'Cear et le philosophe primitiviste Mac Adam, ainsi que leurs épouses Mrs. Connan O'Connan, Mrs. Grégor Mac Connan, Mrs. Mack O'Grégor Mac Connan, Mrs. O'Cear et Mrs. Mac Adam et leur fils George Connan O'Connan, Phil Mac Connan, Timoléon Mac Connan, Padraic O'Grégor Mac Connan, Arcadius O'Cear, Augustin O'Cear, César O'Cear, Abel Mac Adam, et Caïn Mac Adam, et leurs filles Irma Connan O'Connan, Sarah Mac Connan, Pelagia Mac Connan, Ignatia O'Grégor Mac Connan, Arcadia O'Cear, Beatitia Mac Adam et Eva Mac Adam, ainsi que le jeune irlandisant timide du tram : Barnabé Pudge» [19, p. 28].

This list enumerating one major and twenty-six minor characters, most of which do not appear in the text other than within similar lists, is more than expressive. Thus, within twenty-six names we observe the repetition of the component Connan nineteen times, Grégor - six times, Cear - six times, Adam - six times. The components $O^{\prime}$ and Mac serve as indicators of 'irishness', the latter one being used simultaneously with Mack, the compo- nent performing the function of the first name. The fact of phonetic resemblance of the two components makes them function as a paronomasia.

As far as the origin and connotative semantics of names are concerned, it is important to note that the author created a nice mix worthy of his postmodernist successors. Biblical names are introduced forming nice oppositions within the list: Abel Mac Adam et Caïn Mac Adam or even within a name: Eva Mac Adam. Inherently Irish and British names are invaded by names of Greek statesmen and Roman emperors: Timoléon (Corinthian statesman [11, p. 75]) Arcadius (the ruler of the "new" Eastern Empire [5, p. 31]), Augustin (the first emperor of Rome and founder of the Roman Empire [5, p. 57]), and César (the best known Caesar is Gaius Julius Caesar, who laid the foundations of the Roman Empire [5, p. 86]). The feminine names at the end of the list, as it can be concluded, are toponyms and hagionyms of the ancient world: Ignatia is an ancient city in Italy known for two small subterranean chapels with paintings of the 11th century A.D. [12, p. 165]; Pelagia is a name of a saint who used to be a sinner [13, p. 788]; Arcadia was the central part of Peloponnesus [11, p. 153], now the name is used to denote idyllic pastoral life; Beatitia is coined from Latin beātitās meaning 'felicity' [16, p. 90], the word, from which beatification, the first step towards canonization, is derived. Therefore, the female names of the list are related to the classical antiquity, religion, and happiness. Allusions to antiquity are present throughout the whole «Journal intime»; we find those allusions in at least one more list: «Et pourtant, le Tarzan en question, il est aussi beau gosse qu'Apollon ou Hermès ou Hercule» [19, p. 67].

The presence of the Dickensian name Barnabé Pudge [22, p. 144] in the long list mentioned above makes it even more colourful. To sum up, the cited list does not serve as a proof of insignificance, but it generates new meanings and serves as a net of allusions helping the interpretation of the novel. We find the names of the above mentioned list in at least two other similar lists, which were shortened due to the less abundant use of last names.

Another list contains a set of abbreviations: "Je peux en parler en connaissance de cause moi qui fais partie de la C.A.C.C.F. A. (Catch-as-catch-can Feminine Association), de la F.I.F.A. (Full-in Feminine Association) et de la G.R.W.F.A. (Greco-roman Wrestling Feminine Association)" [19, p. 88]. The three mentioned abbreviations, as some scholars suggest, were inspired by advertisement [4, p. 77], the proof of that fact can be found in the article by René Etiemble, which appeared a few years after "Les œuvres complètes de Sally Mara» did. In this article the author characterized the advertisement of that period, paying attention to the abuse of abbreviations and sigles [8, p. 106]. It is superfluous to say that the mentioned organizations did not and do not exist, moreover, the 'decoding' of the names reveals their relatedness to the sphere of sports: catch-as-catch-can is a kind of wrestling style [6], full-in is a double salto with a full twist [21, p. 78]. Raymond Queneau could be familiar only with FIFA (Fédération Internationale of Football Association) as a real-life organization, the rest are the fruit of his imagination. We consider the above mentioned abbreviations to be fictional proper names. They serve the purposes of irony. 
The following enumeration is based on the principle of patchwork: "Voire, comme disait Montaigne, mettons nos manchettes, comme disait Buffon, et paix à la syntaxe, comme disait Victor Hugo» $[19$, p. 63]. Names and expressions are placed one after another, without creating any meaningful phrase. The expression paix à la syntaxe really belongs to Victor Hugo: Guerre à la rhétorique et paix à la syntaxe! [15, p. 32]. By Buffon the author means Georges Louis Leclerc, comte de Buffon, who was ridiculed by his compatriots d'Alembert and Condorcet for the pomp, with which he put on his oversleeves to write [14]. And, finally, the initial voire is the characteristic feature of Montaigne's writing [18, p. 151]; therefore, the author evidently implies the syntax of this French author. Thus, this enumeration is not intelligible for anyone, who is not aware of French literature, science and history. Does this enumeration make any sense? Within its context it definitely does. The author, Sally Mara, expresses her desire to become une femme de lettres - female writer before enumerating all these names and expressions. If all the proper names in this list can somehow fit in one paradigm; let us call it 'the men of writing', their expressions, nevertheless do not form a coherent expression and serve to create absurdity.

The enumeration of British artists in the following list really looks as the one underlying the insignificance of its components: «Je m'attendris, comme d'habitude, devant le portrait de Stella, ne me sentis pas le courage de monter au premier étage pour voir les tableaux de Leslie, Maclise, Mulready, Landseer et autres Wilkie et allai me promener dans le jardin» [19, p. 36]. The insignificance is encoded with the help of et autres Wilkie meaning 'and other Wilkies'. The sexual subtext of the story may imply the connection between these "other Wilkies" and British slang willy, denoting penis and used since 1905 [7, p. 1057].

One more list we find in "Sarah plus intime», which is a set of expressions containing language play, puns in particular, forming a separate section of «Les œuvres»: «Poueun, Phoueun, Phouon ou Moung-Phouon, population du Laos annamite, naguère organisé en royaume, tributaire de celui de Vien-Chang. Les villages poueun sont d'une malpropreté remarquable.» (Nouveau Larousse Illustré, t. VI, p. 1053, col. 3) [19, p. 352]. We have checked the source indicated by R. Queneau and we can affirm that the quotation is exactly the same as it is in the encyclopedia (see [2, p. 1053]); it is neither a mystification nor any other author's invention. What is funny about this article is the last phrase: Les villages poueun sont d'une malpropreté remarquable. The phonological structure of the component poueun is similar to French puer, puant - 'smell bad', therefore, the sentence might imply that the smelly villages are exceptionally dirty. The list at the beginning of the encyclopaedic article creates a sort of phonetic play, which can be transcribed as the following [pu-

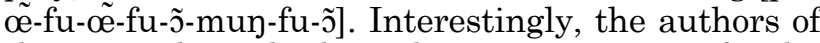
the original article chose the most expressive for the French ear component to describe the dirty villages.

Conclusions. Lists are an important element of text, no matter what literary movement the work of literature belongs to. In the surrealist prose by Raymond Queneau lists of proper names serve several purposes. They are phonetically expressive; their implications on the semantic level permit new layers of interpretation. Raymond Queneau's lists are similar to the postmodern ones, as they also perform metafictional and self-reflexive function. They imply the artificiality and fictitiousness of described events and characters. At the same time they are an element of humour, as they serve to form puns, ironic and absurd expressions. Lists of proper names compared to lists of appellatives have a higher potential to serve as allusions, therefore they are more expressive on the semantic level.

Further research might involve more profound study of Raymond Queneau's lists both in his prose and poetry.

\section{References:}

1. Alber, J. (2016). Absurd catalogues: the functions of lists in postmodernist fiction. Style. Vol. 50(3), pp. 342-358.

2. Augé, C., ed. (1903). Nouveau Larousse Illustré. T. 6. Paris: Librairie Larousse.

3. Bary, C. (2011). Les listes oulipiennes. Poétique, no. 168, pp. 415-429.

4. Bourdette-Donon, M. (1994). Des Fautes de françoise au génie linguistique ou Raymond Queneau, un exemple de plurilinguisme littéraire. Francofonia, 26, pp. 75-86.

5. Bunson, M. (2014). Encyclopedia of the Roman Empire. New York: Infobase Publishing.

6. Catch-as-catch-can (2018, April 10). Encyclopcedia Britannica. Retrieved May 9, 2020, from https://www.britannica.com/ sports/catch-as-catch-can-wrestling

7. Dalzell, T., ed. (2009). The Routledge dictionary of Modern American Slang and Unconventional English. New York - London: Routledge.

8. Etiemble, R. (1965). La langue de la publicité. Communication \& Langages, 15, pp. 105-112.

9. Folkart, B. (1986). Traduction et remotivation onomastique. Meta, vol. 31, num. 3, pp. 233-252.

10. Full, B., \& Lecolle, M. (2018). Jeux de mots et créativité. Berlin - Boston: De Gruyter.

11. Gagarin, M. (2010). The Oxford encyclopedia of ancient Greece and Rome. Vol. 1. Oxford: Oxford University Press.

12. Gnatia (1911). In Encyclopcedia Britannica. Vol. 12. New York: Horace Everett Hooper, p. 165.

13. Holweck, F.G. (1924). A Biographical dictionary of the saints. St. Louis - London: Herder Book.

14. Hoquet, T. (2007). Georges Louis Leclerc, comte de Buffon. FranceArchives. Retrieved May 10, 2020, from https://francearchives.fr/commemo/recueil-2007/39340

15. Hugo, V. (1856). Les Contemplations. Paris: Nelson.

16. Lewis, Ch.T. (1890). An Elementary Latin dictionary. New York - Cincinnati - Chicago: American Book Company.

17. Milcent-Lawson, S., Lecolle, M., \& Michel, R. (2013). Liste et effet liste en literature. Paris: Classiques Garnier, coll. "Rencontres".

18. Papić, M. (1970). L'expression et la place du sujet dans les Essais de Montaigne. Paris: Presses Universitaires de France.

19. Queneau, R. (1962). Les œuvres complètes de Sally Mara. Paris: Gallimard, coll. "L'Imaginaire".

20. Queneau, R. (1981). Courir les rues. Paris: Gallimard, coll. "Poésie".

21. Striesend, J. (2013). Illustrated dictionary of sports. Dehli: Lotus Press.

22. Stump, J. (1998). Naming and unnaming on Raymond Queneau. Lincoln - London: University of Nebraska Press. 